\title{
The multiplicity of malaria transmission: a review of entomological inoculation rate measurements and methods across sub-Saharan Africa
}

\author{
Louise A Kelly-Hope*1,2 and F Ellis McKenzie ${ }^{2}$
}

\author{
Address: ${ }^{1}$ Vector Group, Liverpool School of Tropical Medicine, Liverpool, UK and ${ }^{2}$ Division of International Epidemiology and Population \\ Studies, Fogarty International Center, National Institutes of Health, Bethesda, MD, USA \\ Email: Louise A Kelly-Hope* - L.Kelly-Hope@liverpool.ac.uk; F Ellis McKenzie - mckenzel@mail.nih.gov \\ * Corresponding author
}

Published: 23 January 2009

Malaria Journal 2009, 8:19 doi:10.1186/1475-2875-8-19

This article is available from: http://www.malariajournal.com/content/8/1/19

(c) 2009 Kelly-Hope and McKenzie; licensee BioMed Central Ltd.

This is an Open Access article distributed under the terms of the Creative Commons Attribution License (http://creativecommons.org/licenses/by/2.0), which permits unrestricted use, distribution, and reproduction in any medium, provided the original work is properly cited.

\begin{abstract}
Plasmodium falciparum malaria is a serious tropical disease that causes more than one million deaths each year, most of them in Africa. It is transmitted by a range of Anopheles mosquitoes and the risk of disease varies greatly across the continent. The "entomological inoculation rate" is the commonly-used measure of the intensity of malaria transmission, yet the methods used are currently not standardized, nor do they take the ecological, demographic, and socioeconomic differences across populations into account. To better understand the multiplicity of malaria transmission, this study examines the distribution of transmission intensity across sub-Saharan Africa, reviews the range of methods used, and explores ecological parameters in selected locations. It builds on an extensive geo-referenced database and uses geographical information systems to highlight transmission patterns, knowledge gaps, trends and changes in methodologies over time, and key differences between land use, population density, climate, and the main mosquito species. The aim is to improve the methods of measuring malaria transmission, to help develop the way forward so that we can better assess the impact of the large-scale intervention programmes, and rapid demographic and environmental change taking place across Africa.
\end{abstract}

\section{Background}

Malaria is the most common, serious mosquito-borne disease in the world [1], yet the tools and methods used to measure the intensity of its transmission are currently not standardized, nor do they take the ecological, demographic, and socioeconomic differences across populations into account [2-7]. This limits the potential for valid spatial-temporal comparisons, and for proper evaluations of the impact of interventions and environmental changes. The recent resurgence in large-scale malaria control programmes, extensive land use changes and the beginnings of significant global climate change make these limitations increasingly important $[8,9]$.

Today, the greatest burden of malaria occurs across subSaharan Africa, where Plasmodium falciparum, the most severe of the parasite species that infect humans, is estimated to cause approximately 250 million cases and nearly one million deaths each year [1]. Malaria in subSaharan Africa is transmitted by a range of Anopheles mosquitoes and the risk of infection and disease vary greatly across the continent. The intensity of malaria transmis- 
sion may be measured several ways, however, the entomological inoculation rate (EIR) is considered a more direct measure of transmission intensity than incidence, prevalence or other traditional epidemiological estimates. EIR is a commonly used metric that estimates the number of bites by infectious mosquitoes per person per unit time [10]. It is the product of the "human biting rate" - the number of bites per person per day by vector mosquitoes - and the fraction of vector mosquitoes that are infectious (the "sporozoite rate") [11].

Understanding the dynamics of malaria transmission in a population is critical; it provides insight into the magnitude of the problem, helps to define when and where the greatest risk occurs and facilitates the development of appropriate control strategies [12-15]. Furthermore, it is important to determine how the level of risk within a population may compare with other (or surrounding) populations - this will help identify key differences and similarities and highlight corresponding risk factors. It is a well-known, but still sparsely-documented fact in subSaharan Africa, that villages only a few $\mathrm{km}$ apart can have EIRs differing $10 \times$ or more, and that such differences can profoundly affect factors such as the prevalence of infection, age incidence and symptomatic presentation of clinical disease, development of immunity, drug use and drug resistance [16-18]. Measuring transmission over longer periods can also help define intra- and inter-annual variability as well as assess the impact of changes within a population such as the introduction of a particular intervention (e.g. indoor residual spraying (IRS) of insecticides and distribution of insecticide-treated bed nets (ITNs)) [19-21], migration, and/or changes in climate and land use patterns (e.g. irrigated agriculture, urbanization) [4-6].

Several recent reviews of EIR data [4-6], have helped to highlight the variable spatial and temporal patterns of malaria transmission, differences between demographic and ecological settings - especially urban and rural populations - and the use of a range of methods to measure transmission across Africa. Importantly, these reviews note the absence of data standardization between studies, raise issues of data quality and information technology, and suggest improvements for future studies.

However, there remains a lack of consensus among the malaria science community and those involved in vector control activities, regarding the best and most efficient way to measure malaria transmission. To address this issue and to better understand the multiplicity of malaria transmission, this current study builds on the recent comprehensive review by Hay et al [6]. Specifically, it examines the distribution of annual EIRs across sub-Saharan Africa, reviews the range of methods used, explores eco- logical parameters in selected locations and makes a series of recommendations regarding the way forward.

\section{Methods}

The analyses in this study are primarily based on the information available from the systematic meta-analysis of annual P. falciparum (APf) EIRs carried out by Hay et al [6], which included 233 APf EIR estimates, from 23 countries across Africa between 1980 and 2004. All references and data may be obtained from the original paper [6]. Additional information on the measurement methods and main Anopheles mosquito species were obtained from the geo-referenced database found on Mapping Malaria Risk in Africa (MARA/ARMA) website [22], based on Hay et al [4], and supplemented with data from the literature.

First, to examine the distribution of APf EIRs across subSaharan Africa over the 25 year time period, each estimate with a geographic reference i.e. latitude and longitude, was compiled in a database, and mapped using the geographic information system (GIS) software ArcGIS (ESRI 9.2, Redlands, CA). Data were summarized by country, and differences in demography, topography and climate were explored by examining the relationship between APf EIRs, and population density (persons per $\mathrm{km}^{2}$ ), elevation (metres above sea level) and climate suitability (number of months) using the Gridded Population of the World Version 3 (GPWv3) [23,24], Global 2' Elevation Data, ETOPO2 [25] and Seasonal Climatological Suitability for Malaria Transmission [26] maps respectively; the latter map is based on the number of months during the year when climatological averages meet empirically-derived thresholds of precipitation, temperature and relative humidity, and provides more detailed information than the one developed by Craig et al [27]. At each APf EIR location, the corresponding/underlying data on population density, elevation and climate suitability were extracted in ArcGIS and exported for analysis. All descriptive and statistical analyses were undertaken in Microsoft Excel and SPSS 15.0 (SPSS, Inc, Chicago, IL).

Second, in order to fully understand the range of methods used to measure APfEIRs, all geo-referenced estimates with information on the human biting rate sampling and sporozoite rate detection techniques (the two main measurement components) were compiled. Data were stratified by the different methods, time and location to determine if there were distinct patterns of usage. Further, the study examined the main measurement methods, it stratified APfEIRs by land use categories Urban, Periurban, Rural $1\left(100-250\right.$ persons per $\left.\mathrm{km}^{2}\right)$ and Rural 2 $\left(<100\right.$ persons per $\left.\mathrm{km}^{2}\right)$ as defined by Hay et al [6], and tabulated differences between main categories of population density, elevation and climate suitability. In addition, data related to the main mosquito species complexes 
Anopheles gambiae and Anopheles funestus were summarized.

Third, to explore the relationship between urban and adjacent rural locations, areas with large differences in APf EIRs that had been measured using the same method, were at similar elevations and within close proximity $(\leq$ $20 \mathrm{~km}$ ) were examined as case studies. Estimates were plotted against maps and satellite images showing the a) 'Urban-Rural Extent' - a global database of urban extents developed as part of the Global Rural-Urban Mapping Project (GRUMP) [24,28], b) 'Earth at Night (City Lights) $5 \mathrm{~km}$ ' - NASA (layer) night-time lights view of the Earth $[29,30]$, c) 'Cloud Free Earth 1 km' - NASA (layer) symbolized display presentation of the World Cloud Free image data set [31], d) African Land Cover at 150 m resolution (Earth Satellite Corporation) [32].

\section{Results}

\section{APfEIR distributions}

In total, APf EIR estimates were available from 23 (43\%) of the 54 African countries (Table 1), with 56\% of the measures from four countries alone; Kenya $(\mathrm{n}=50)$, Burkina Faso $(n=30)$, Tanzania $(n=26)$ and The Gambia $(n=25)$. The geographical distribution of all geo-referenced APf EIR estimates $(\mathrm{n}=230)$ is shown in Figure 1, and highlights the large differences found within and between countries, with values ranging from 0 to 1,030

Table I: Summary of APf EIR estimates by country

\begin{tabular}{|c|c|c|}
\hline Country & $\mathbf{N}$ & Average APf EIR \\
\hline Benin & 6 & 31.5 \\
\hline Burkina Faso & 30 & 100.6 \\
\hline Burundi & 5 & 251.6 \\
\hline Cameroon & 14 & 184.9 \\
\hline Congo & 4 & 186.6 \\
\hline Congo (D.R) & 6 & 231.0 \\
\hline Cote d'Ivoire & 2 & 314.7 \\
\hline Egypt & 2 & 0.9 \\
\hline Equatorial Guinea & 2 & 814.3 \\
\hline Eritrea & 8 & 14.6 \\
\hline Gabon & 6 & 108.4 \\
\hline Gambia & 25 & 34.8 \\
\hline Ghana & 1 & 418.0 \\
\hline Kenya & 50 & 43.4 \\
\hline Liberia & 4 & 21.9 \\
\hline Madagascar & 5 & 39.5 \\
\hline Mali & I & 3.6 \\
\hline Mozambique & I & 52.9 \\
\hline Nigeria & 1 & 48.0 \\
\hline Senegal & 19 & 25.3 \\
\hline Sierra Leone & 14 & 155.7 \\
\hline Sudan & 1 & 0.6 \\
\hline Tanzania & 26 & 285.2 \\
\hline Total & 233 & I 12.2 \\
\hline
\end{tabular}

infective bites per person, per annum. Figure 1 also shows the huge geographic gaps (e.g. Congo) in APf EIR estimates.

The examination of APf EIRs by population density, elevation and climate suitability indicated that the highest rates occurred in less populated (i.e. rural) places, at sites between $100 \mathrm{~m}$ and 1,000 $\mathrm{m}$ elevation, and in locations with a higher number of climatically suitable months (Figure 2). For example, average APf EIRs, were i) 5 times higher in locations with less than 1,000 person per $\mathrm{km}^{2}$ $($ APf EIR $=98.7)$ compared with those with more than 1,000 persons per $\mathrm{km}^{2}(19.4)$; ii) 1.5 to three times higher in locations at 100 to $1,000 \mathrm{~m}($ APf EIRs $=167)$ compared with those at lower (49.8) or higher elevations (90.4) and; iii) five times higher in locations with seven or more months $(\mathrm{A} P f \mathrm{EIRs}=270.5)$ of climate suitability compared with those with six or less (55.5). Figure 2 also shows that a high proportion of measurements were recorded in populations of low density i.e $0-100$ per $\mathrm{km}^{2}$ $(\mathrm{n}=130 ; 57 \%)$, in low elevations i.e. $0-100 \mathrm{~m}(\mathrm{n}=97$; $42 \%$ ) and in locations with five to six months climate suitability $(\mathrm{n}=89 ; 39 \%)$.

The relationship between APfEIRs and each dependent variable was further examined using bivariate correlations, Pearson's correlation coefficient ( 2 tailed $P$ values $\leq$ 0.05 significance). Due to the large differences in APfEIRs, population density and elevation estimates, these variables were first transformed to the natural logarithm (log). Analyses indicated a significant negative correlation between APfEIRs and population density $(r=-0.298, P \leq$ $0.01)$, and significant positive correlation with elevation $(\mathrm{r}=0.288, P \leq 0.01)$ and climate suitability $(\mathrm{r}=0.456, P$ $\leq 0.01)$.

\section{APfEIR measurement methods}

In total, 199 study locations reported both the human biting rate sampling and sporozoite rate detection technique. Overall, eleven different methods used to measure APf EIRs between 1980 and 2004 were identified (Table 2). Human biting rates were most commonly determined using human bait collections (HBC) or pyrethrum spray catches (PSC), however, light traps and window exit traps were also used in some regions and in combination with other methods. Sporozoite rates were primarily determined by the dissection of mosquito salivary glands [3], or by enzyme-linked immuno-sorbent assays (ELISA) [33]. Only one study used the more recently developed polymerase chain reaction (PCR)-based method [34].

Table 2 highlights the overall increasing trend of APfEIR measurements over time with a total of 21 in 1980-84, and 71 in 1995-99. This table also shows the range of combined methods used, and how their frequencies of 


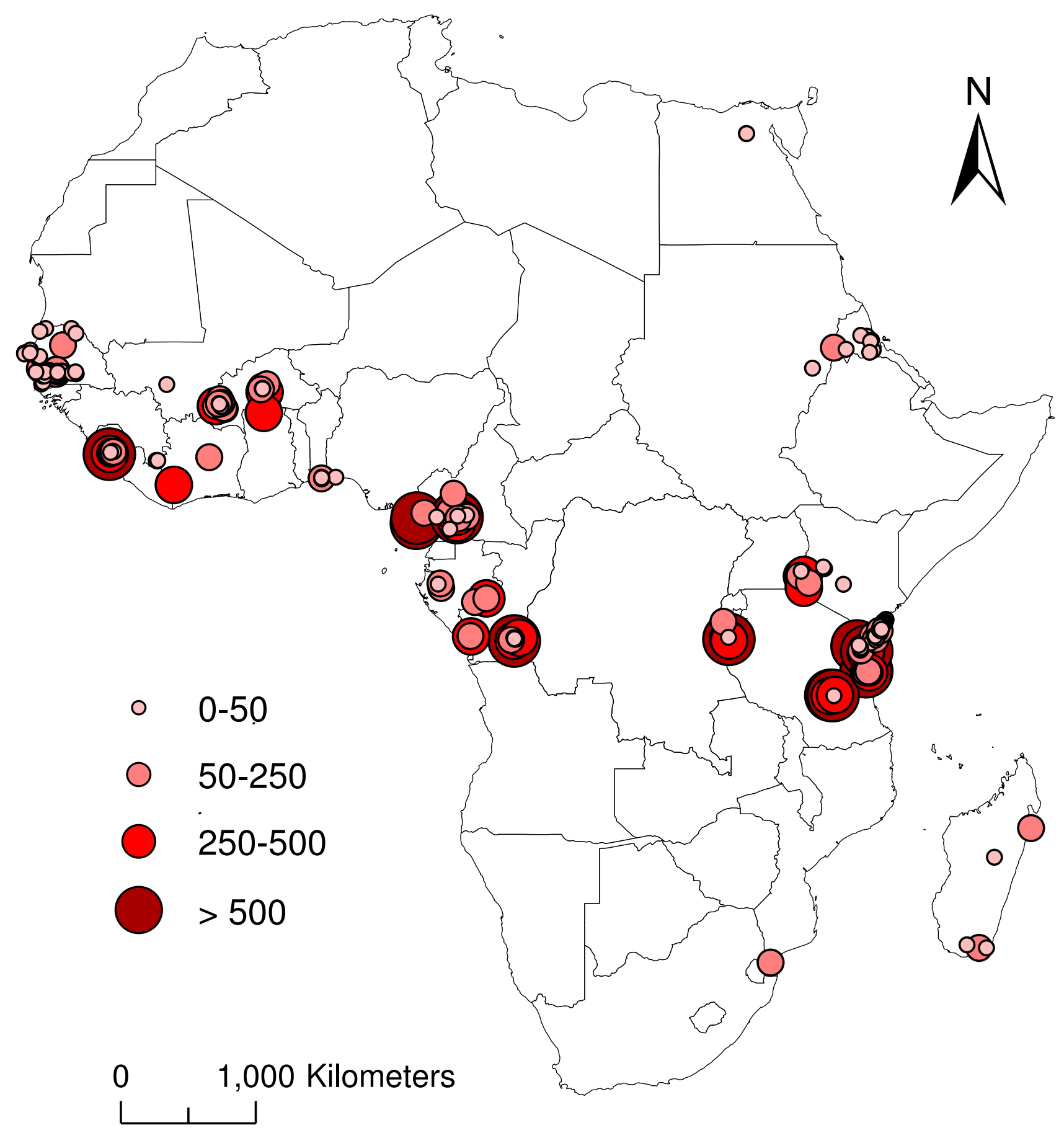

Figure I

The magnitude and geographical distribution of annual APf EIR estimates across Africa between I980 and 2004.

use changed over time. New methods joined, but did not entirely replace the old, e.g., as the combinations reported rose from two in the early 1980s to seven in the late 1990 s, the use of PSC+ELISA rose from $0 \%$ to $44 \%$ of estimates, while HBC+dissection dropped from $62 \%$ to $15 \%$.
There was no distinct geographical pattern in the methods, as illustrated over four different time periods in Figure 3. In some regions, several different methods had been used to measure APf EIRs (Figure 4). 

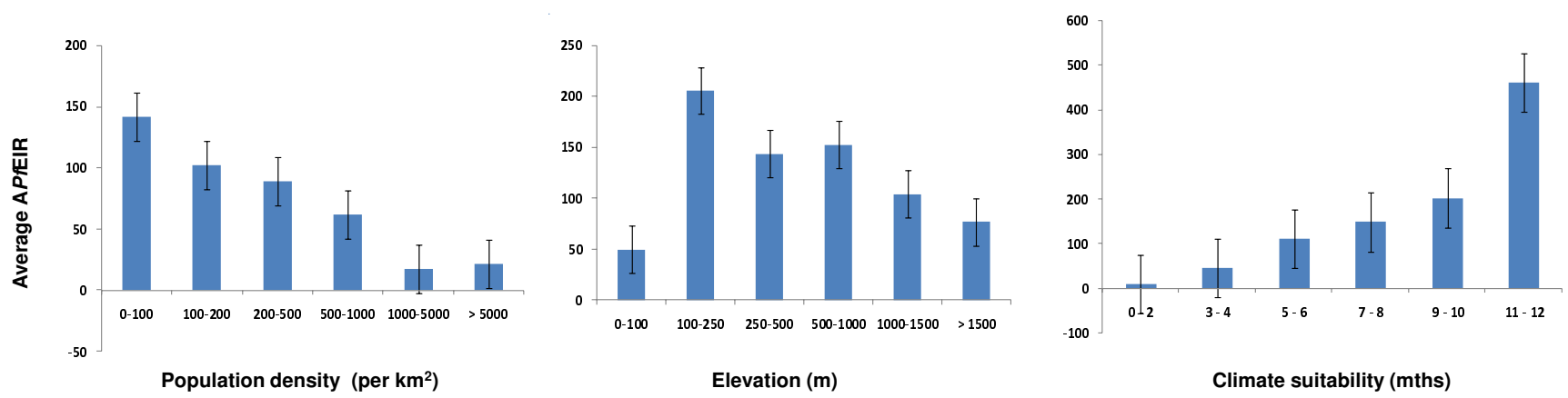

\section{Figure 2}

Average APfEIR estimates by population density, elevation and climate suitability groupings. Note. Numbers (n) for population density categories 0-100 $(n=130), 100-200(n=26), 200-500(n=38), 500-1000(n=12), 1000-5000(n=$ $13),>5000(n=11)$; for elevation categories 0-100 ( $n=97), 100-250(n=38), 250-500(n=54), 500-1000(n=23) 1000-$ $1500(n=13)$, > I500 $(n=5)$ and; for climate suitability categories 0-2 $(n=16) 3-4(n=51), 5-6(n=89), 7-8(n=46), 9-10$ $(n=25), 11-12(n=3)$.

Overall, the HBC+dissection $(\mathrm{n}=61), \mathrm{HBC}+\mathrm{ELISA}(\mathrm{n}=$ $38)$, PSC+ ELISA $(\mathrm{n}=42)$ and light trap+ ELISA $(\mathrm{n}=32)$ combinations were the most frequently used methods, and comparisons of mean APf EIRs by land use categories showed that these four different methods exhibited different patterns (Figure 5). Significant differences were found between Urban and Rural 2 locations when measured using all methods (in accordance with Hay et al [6]), or $\mathrm{HBC}+$ dissection, however, these trends were not evident when other methods were used. Further, the light trap+ELISA method was found to have been used only in rural locations, predominantly Rural 2.

The trends shown in Figure 2 persisted across the different measurement methods, and are summarized in Table 3.
Due to the relatively small numbers in each measurement group, the dependent variables were examined by two main categories to highlight overall differences in average APfEIRs. Means were compared using the Mann-Whitney $U$ test with Bonferroni correction for multiple comparisons (adjusted $P$ values $\leq 0.004$ significance). Overall, locations with low population density $(\leq 500$ persons per $\mathrm{km}^{2}$; APf EIR $\left.=105.4\right)$ and more months of climate suitability ( $>5$ months; APf EIR $=132.8)$ had significantly higher rates than those with high population density ( $>500$ persons per $\mathrm{km}^{2} ;$ APf EIR $\left.=73.9\right)$, and fewer months $(0-5$ mths; APf EIR = 77.5). Overall, there was no significant difference between locations with lower ( $\leq$ 500; APf EIR = 101.1) and higher $(>500 ; \mathrm{APf}$ EIR = 137.0) elevation.

Table 2: Number of times the different APfEIR methods were used (at different time intervals) over the 25 year study period

\begin{tabular}{|c|c|c|c|c|c|c|}
\hline \multirow[t]{2}{*}{ Sporozoite Detection and Biting Rate Method } & \multicolumn{5}{|c|}{ Year intervals } & \multirow[b]{2}{*}{ Row Total } \\
\hline & $1980-84$ & $1985-89$ & $1990-94$ & 1995-99 & 2000-04 & \\
\hline Dissection + HBC & 13 & 19 & 18 & 11 & - & 61 \\
\hline Dissection + PSC & 8 & - & - & - & - & 8 \\
\hline Dissection + Exit Trap & - & 2 & - & - & - & 2 \\
\hline Dissection + ELISA + HBC & - & - & - & 1 & - & 1 \\
\hline ELISA + HBC & - & 9 & 14 & 13 & 2 & 38 \\
\hline ELISA + PSC & - & - & II & 31 & - & 42 \\
\hline ELISA + Light Trap & - & 13 & 10 & 9 & - & 32 \\
\hline ELISA + HBC + PSC & - & - & 4 & - & - & 4 \\
\hline ELISA + HBC + PSC + Light Trap & - & - & - & 3 & - & 3 \\
\hline ELISA + HBC + Exit Trap & - & - & 5 & - & - & 5 \\
\hline ELISA + PCR + HBC & - & - & - & 3 & - & 3 \\
\hline Column total & 21 & 43 & 62 & 71 & 2 & 199 \\
\hline
\end{tabular}

Note. Human bait catch = HBC, pyrethrum spray catches = PSC, enzyme-linked immuno-sorbent assays $=$ ELISA, polymerase chain reaction $=$ PCR 
a) $1980-1984$

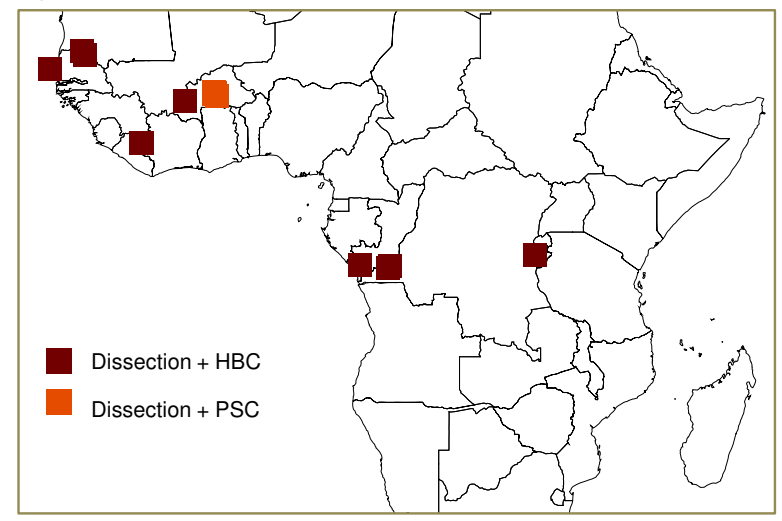

c) $1990-1994$

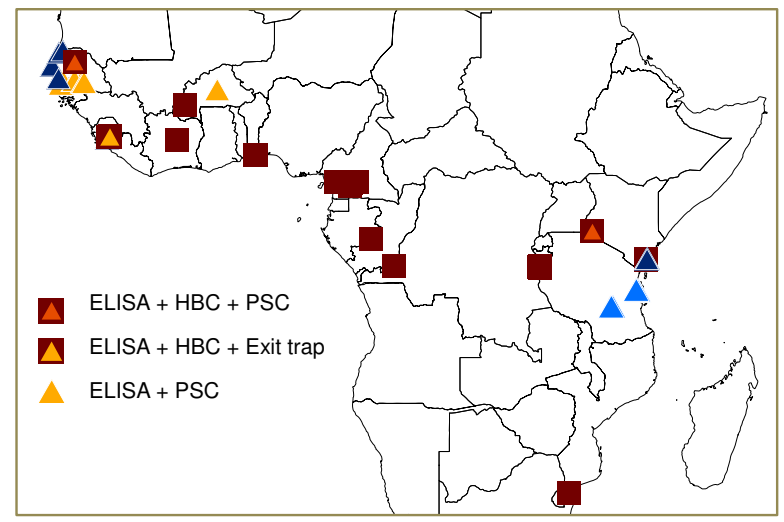

b) $1985-1989$

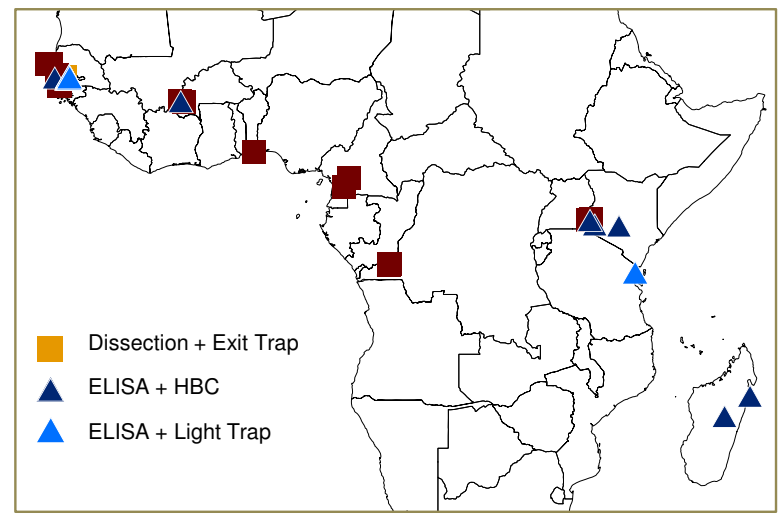

d) $1995-2004$

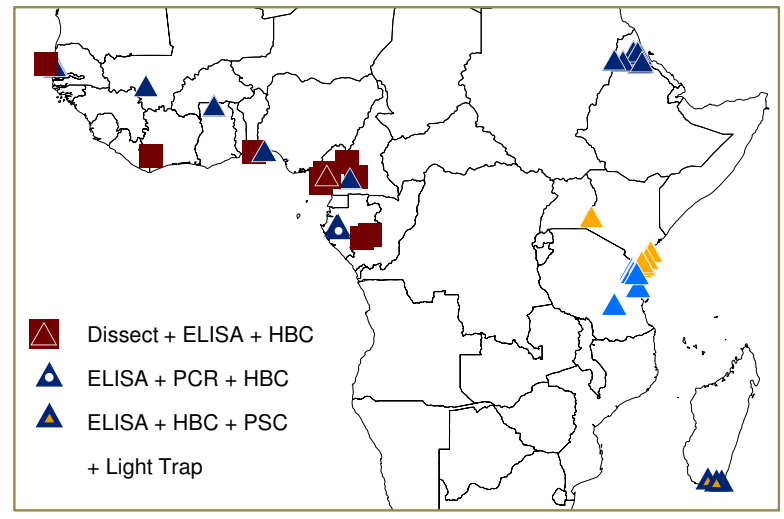

\section{Figure 3}

Geographical distribution of the different methods used to measure malaria transmission at different time intervals between 1980 and 2004 .

There was great variability in the reporting of the two main mosquito species (complexes), An. gambiae s.l and An. funestus, and the degree to which each contributed to malaria transmission. Therefore, these APfEIR comparisons were limited, and examined simply in terms of i) An. gambiae s.l - sole species present or identified as responsible for $100 \%$ of transmission, and ii) An. gambiae + An. funestus - both species present and/or found to be partially responsible for transmission in varying proportions. In total, 187 locations reported information on mosquito species, and overall, average APf EIRs were found to be more than twice as high in locations where both An. gambiae + An. funestus were present (APf EIR = 147; $\mathrm{n}=110)$, than in locations, which only comprised An. gambiae s.l. $(\mathrm{APf}$ EIR $=64 ; \mathrm{n}=77$ ) (Figure 6). Further comparison of the means (Mann-Whitney $U$ test with Bonferroni corrected $P$ values $\leq 0.004)$, of the two species groups by measurement methods, land use, population density, ele- vation and climate suitability categories showed similar trends, with the greatest differences and highest average APf EIRs found in locations of low population densities i.e. rural, those with a high number of climatically suitable months i.e. 6-12, and where the $\mathrm{HBC}+$ dissection method was used (Table 4).

Additionally, there was great variability within each method, particularly for human-biting-rate sampling techniques. Most studies provided little or no explanation regarding the rationale behind the choice of locations, houses, or trap placements, nor information on the human collectors, time of day, or frequency of mosquito collection. It was also found that PSC-based studies did not routinely take the mosquito species composition into account, an omission, which may be important in locations where vectors often rest outdoors after feeding. 


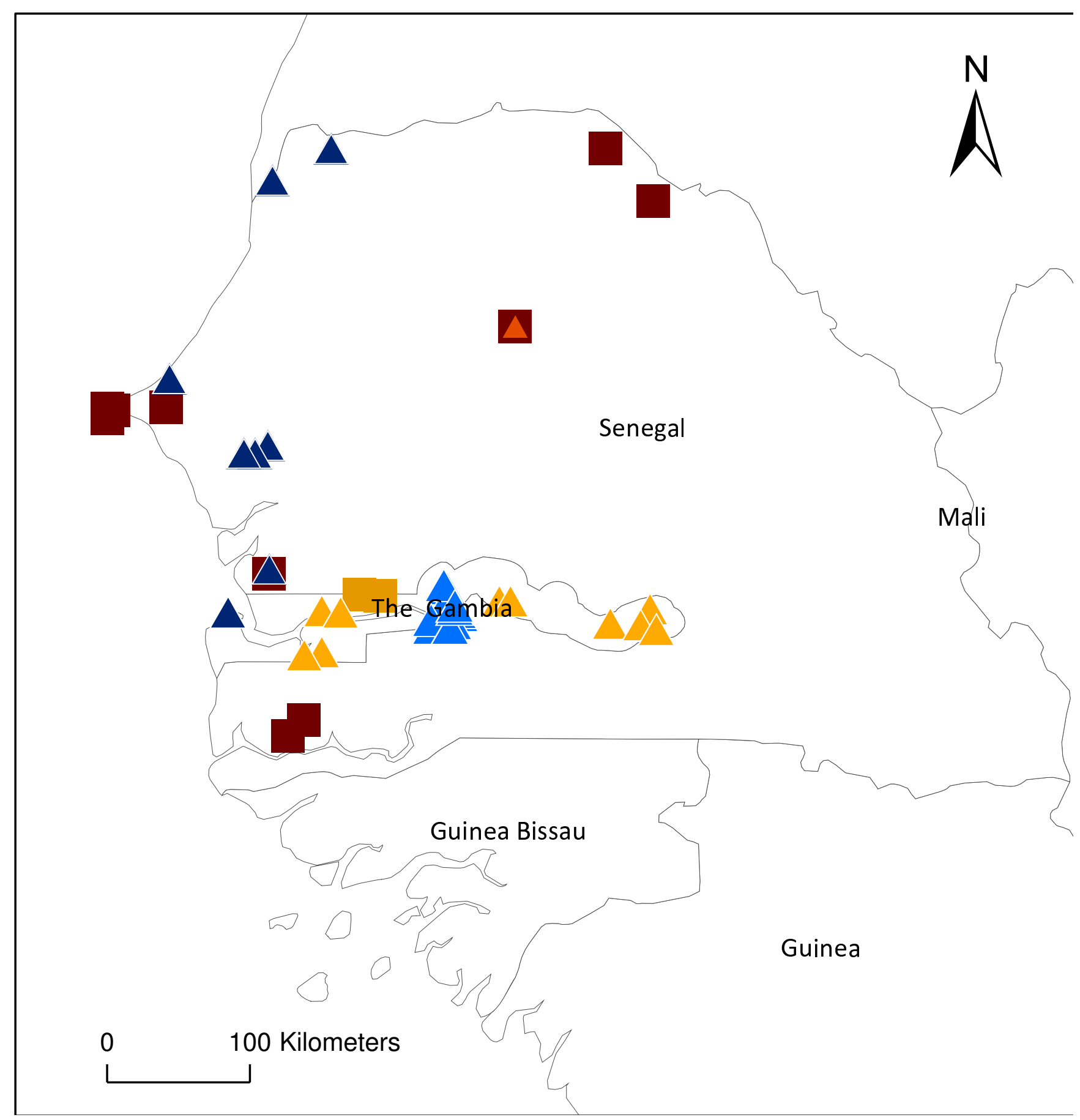

Figure 4

Close-up of the geographical distribution of the measurement methods (Subset of Figure 3).

\section{Case studies}

Burkina Faso (Figure 7, maps a-d)

In 1984, a longitudinal malaria survey was carried out in the capital city, Ouagadougou, and three nearby villages (three months climate suitability) [35]. APf EIRs were determined from PSC and dissections. The main mos- quito vectors were An. gambiae s.l and An. funestus. In urban Ouagadougou (Pop. density 1,560 persons per $\mathrm{km}^{2}$ ), APf EIRs ranged from 0 to 7.7, which were significantly lower than those recorded in a rural village (with irrigation) $10 \mathrm{kms}$ west (APf EIR = 82; Pop. density 1136)), a rural village $15 \mathrm{kms}$ north (APf EIR = 113; 

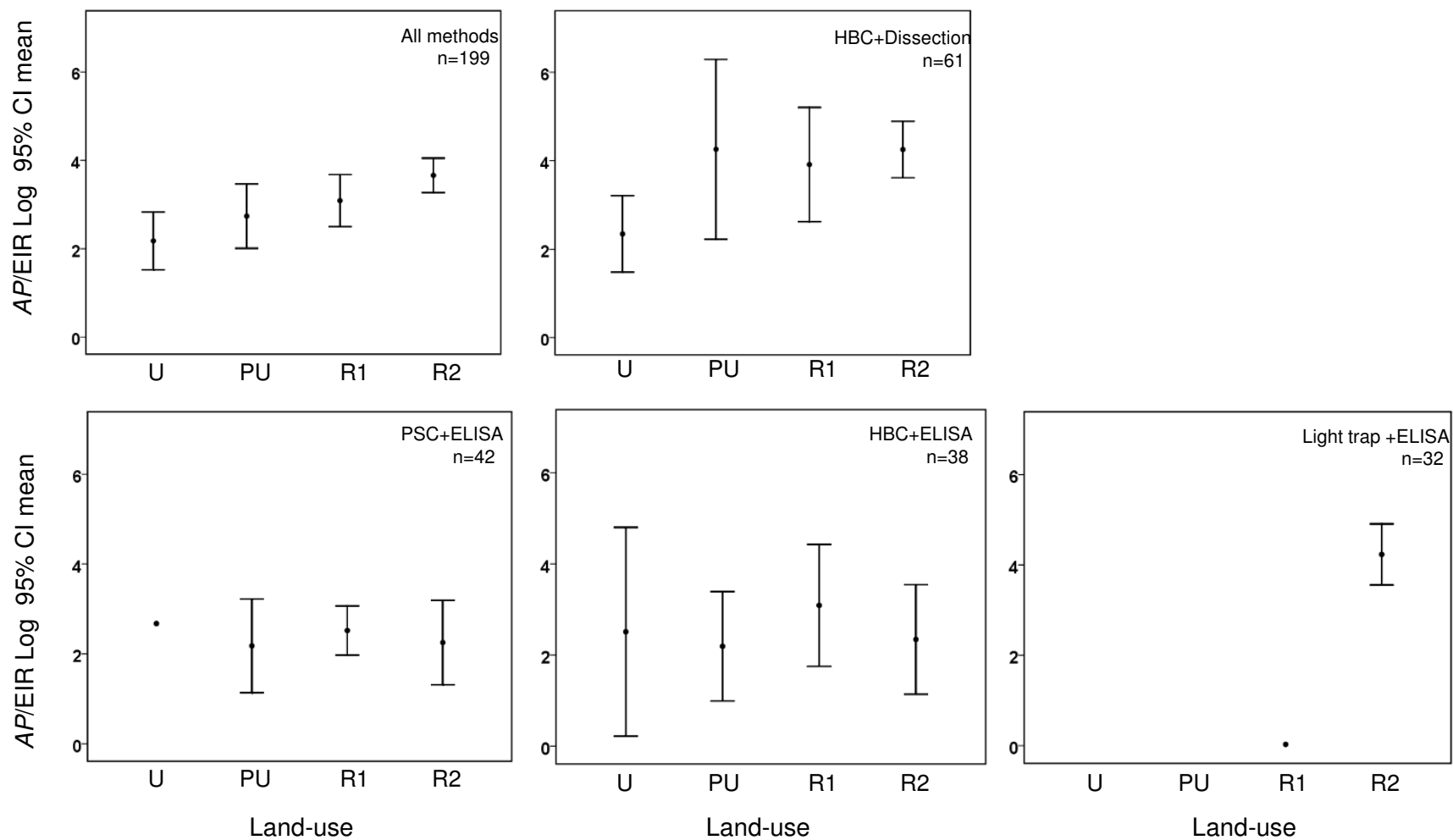

Figure 5

Graphs of APfEIR estimates by four main measurement methods and land use categories.

Pop. density 488) and a rural village $30 \mathrm{kms}$ south (APf $\mathrm{EIR}=442$; Pop. density 67) from the city centre (maps ad). Thus, transmission appeared to increase with distance from the urban area with an estimated 2.5 to 5 rise in APf EIRs per kilometre. The maps further highlight the reduced risk of malaria in urban areas (map a - grey shading) and where city lights prevail (map b).

Benin (Figure 8, maps a-d)

Three studies were undertaken in the coastal town of Cotonou and a village on Nokoué Lake between 1987 and
1995 (eight months climate suitability) [36-38]. APf EIRs were determined from HBC and dissections. The main mosquito vectors were An. gambiae s.s and Anopheles melas; the latter being the most abundant in the lagoon areas, and, although an aggressive biter, considered a poor malaria vector. This may account for the low transmission found in the traditional village by the lake where APf EIRs were 11 (Pop. density 744 persons per $\mathrm{km}^{2}$ ), which was, on average, four times lower than that found in urban Cotonou where APf EIRs ranged between 33 and 58 (Pop. density 3035-12,341), some $10 \mathrm{kms}$ across the lake

Table 3: Average APFEIRs by population density, elevation and climate suitability using different measurement methods

\begin{tabular}{|c|c|c|c|c|}
\hline & HBC + Dissection & HBC + ELISA & PSC + ELISA & Light trap +ELISA \\
\hline \multicolumn{5}{|l|}{ Population density } \\
\hline$\leq 500$ person $/ \mathrm{km}^{2}$ & $198.6(45)^{*}$ & $96.4(32)$ & $21.2(38)$ & $180.7(32)$ \\
\hline$>500$ person $/ \mathrm{km}^{2}$ & $37.0(16)$ & $28.7(6)$ & $20.0(4)$ & (0) \\
\hline \multicolumn{5}{|l|}{ Elevation } \\
\hline$\leq 500 \mathrm{~m}$ & | $47.7(4 \mid)$ & $70.7(26)$ & $20.5(4 I)$ & $206.4(28)$ \\
\hline$>500 \mathrm{~m}$ & $173.9(20)$ & $118.1(12)$ & $46.7(1)$ & $0.9(4)$ \\
\hline \multicolumn{5}{|l|}{ Climate Suitability } \\
\hline $0-5 \mathrm{mths}$ & $62.4(19)^{*}$ & $32.0(30)^{*}$ & $20.5(4 I)$ & $95.3(15)$ \\
\hline$>5$ mths & $198.7(42)$ & $287.1(8)$ & $46.7(I)$ & $256.0(17)$ \\
\hline
\end{tabular}

Note: * denotes statistically significant difference between mean APfEIR estimates in the different population density, elevation and climate suitability groups. 
Table 4: Comparisons of average APfEIRs in the presence and absence of An. gambiae and An. funestus by measurement methods, land use, population density, elevation and climate suitability

\begin{tabular}{|c|c|c|c|}
\hline & An. gambiae s.I $(n=77)$ & An. gambiae + An. funestus $(\mathrm{n}=1 \mid \mathrm{I})$ & Signif. \\
\hline \multicolumn{4}{|l|}{ Measurement Method } \\
\hline HBC + Dissection & $64.3(28)$ & $266.45(29)$ & $*$ \\
\hline $\mathrm{HBC}+\mathrm{ELISA}$ & $86.7(12)$ & $100.7(22)$ & \\
\hline PSC + ELISA & $2.6(15)$ & $31.4(27)$ & * \\
\hline Light trap + ELISA & $103.5(13)$ & $225.36(18)$ & \\
\hline \multicolumn{4}{|l|}{ Land use } \\
\hline Urban & $25.3(12)$ & $27.2(6)$ & \\
\hline Peri-urban & $105.6(6)$ & $86.2(22)$ & \\
\hline Rural I & $90.5(10)$ & $115.7(31)$ & \\
\hline Rural 2 & $63.0(49)$ & $206.2(5 \mathrm{I})$ & $*$ \\
\hline \multicolumn{4}{|l|}{ Population density } \\
\hline$\leq 500$ person $/ \mathrm{km} 2$ & $73.2(63)$ & 159.1 (96) & $*$ \\
\hline$>500$ person $/ \mathrm{km} 2$ & $22.5(14)$ & $63.1(14)$ & \\
\hline \multicolumn{4}{|l|}{ Elevation } \\
\hline$\leq 500 \mathrm{~m}$ & $67.9(64)$ & I34.2 (86) & $*$ \\
\hline$>500 \mathrm{~m}$ & $44.6(13)$ & $192.6(24)$ & \\
\hline \multicolumn{4}{|l|}{ Climate Suitability } \\
\hline $0-5 \mathrm{mths}$ & $24.6(49)$ & $68.0(59)$ & $*$ \\
\hline$>5$ mths & I 32.9 (28) & $238.3(5 \mathrm{I})$ & \\
\hline
\end{tabular}

Note: * denotes statistically significant difference between mean APfEIR estimates in different mosquito species groupings

(maps a-d). Freshwater An. gambiae s.s is considered to be an important vector in urban Cotonou, despite the narrow strip of land between the Atlantic Ocean and Nokoué Lake, on which the town sits.

Republics of Congo (Figure 9, maps a-d)

In the capital cities and surrounding rural areas of the Republic of Congo (Brazzaville) and Democratic Republic of Congo (Kinshasa), entomological studies were carried out between 1981 and 1984, and 1989 and 1991, respectively (eight months climate suitability) [39-42]. APf EIRs were determined from $\mathrm{HBC}$ and dissections. The main vector was An. gambiae s.l. Both cities had similar patterns

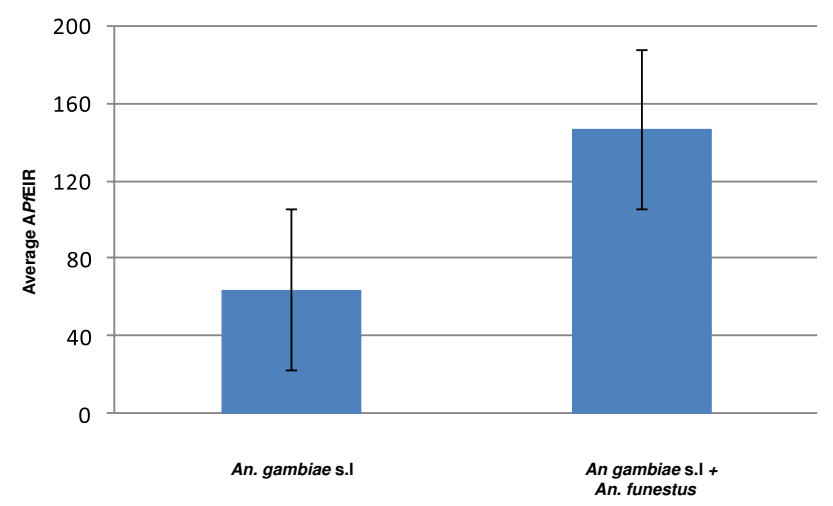

Figure 6

Comparison of average APfEIR estimates by two different mosquito species groupings. with lower transmission (APf EIR; 2.9, 22.5) than the adjoining peri-urban (APf EIR; 31) and rural areas (APf EIR; 24, 246, 620), but with less strongly inverse relationships with population density patterns (Urban/peri-urban Pop. density 208-7954 vs. rural 186-7954). The maps indicate that the urban area of Kinshasa (maps a, b) has grown since the study and now includes areas previously classified as peri-urban and rural. This suggests that the ecology and risk of malaria may have changed in these locations in recent years.

\section{Conclusion}

This review shows the geographical distribution of APf EIR estimates across sub-Saharan Africa, the region at greatest malaria risk in the world [1], and highlights the vast gaps in knowledge on the transmission of this devastating disease. The fact that only half the countries of subSaharan Africa have data available on transmission intensities is of great concern. This dearth of fundamental data raises questions about how current large scale vector control, malaria elimination and eradication programmes currently underway across the continent can develop realistic plans to achieve their goals [43-49]. It emphasizes the need for systematic sampling across a wider geographical area, to include a more diverse range of demographic and ecological settings.

The highest number of APf EIR estimates were taken in rural populations, in particular in locations with $<100$ person per $\mathrm{km}^{2}(\mathrm{n}=130)$. Very few measures were taken in urban areas where the population density was high i.e. > 

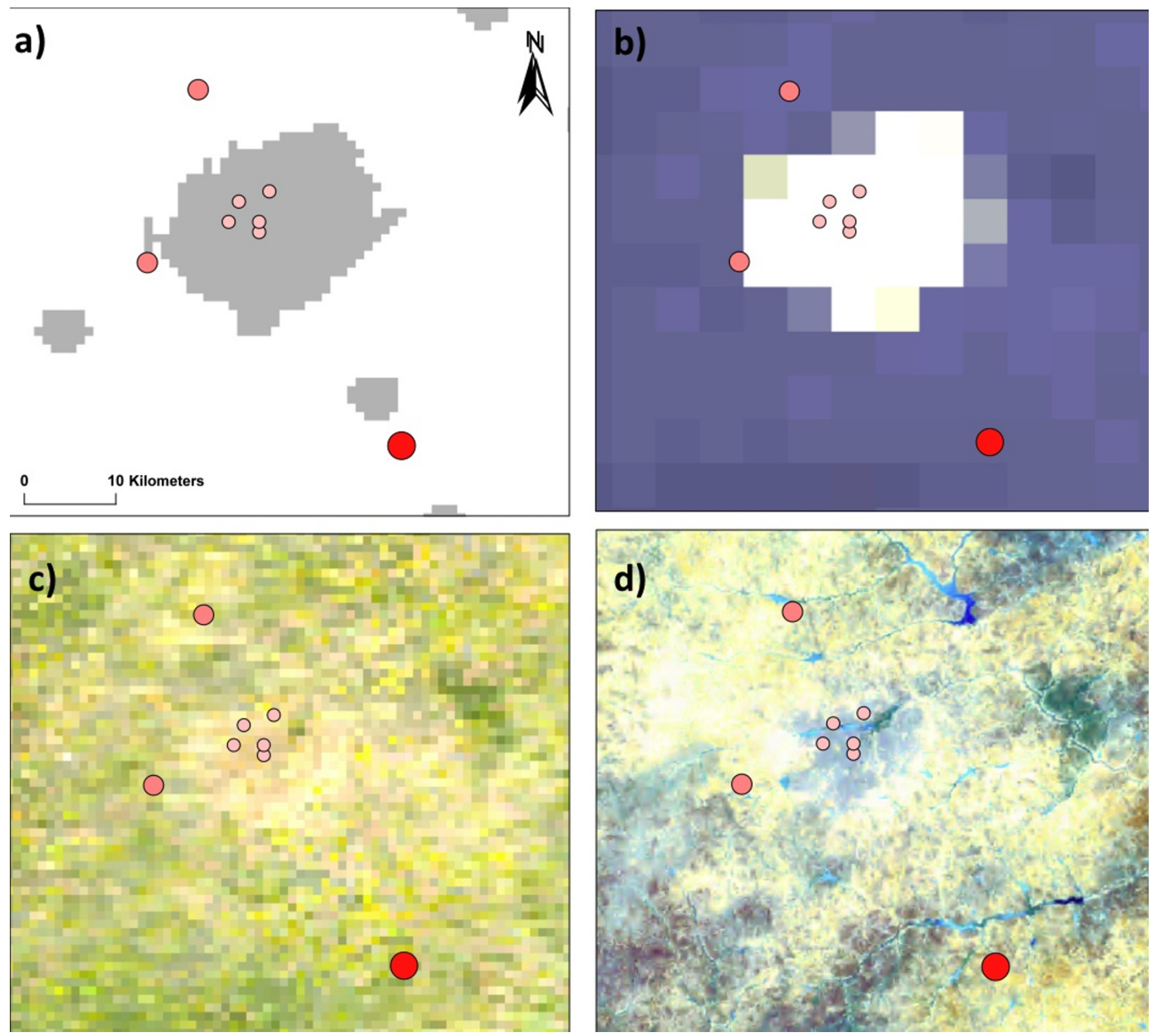

\section{Figure 7}

Burkina Faso case study. a) Urban-Rural Extent b) Earth at Night (City Lights) 5 km c) Cloud Free Earth I km d) African Land Cover at $150 \mathrm{~m}$.

1,000 per $\mathrm{km}^{2}$. Hence, there is a pressing need to know more about urban population transmission dynamics, given the rapid urbanization currently taking place across the continent [50]. It is predicted that more than $60 \%$ of the population in sub-Saharan Africa will be urban dwelling by 2020. The examination of modelled population density to define differing demographic trends, suggests that they may be preferable to the urban-rural categories defined by Hay et al [6], which are potentially subjective e.g. urban areas can vary greatly in population density as elucidated in the three case studies.
Importantly, there was also great variation in the number of estimates taken in areas of different elevations and months of climate suitability. Approximately $40 \%$ of the APf EIR estimates were taken at elevations of $<100 \mathrm{~m}$, and these were, on average, significantly lower than all those taken at higher elevations. This apparent lower risk at lower elevations may be associated with the measurements taken in coastal locations where mosquito species such as An. melas and Anopheles merus prevail, but are considered to be poor vectors of malaria [36-38,51-53]. It may also be related to urban populations, which are usu- 
a)
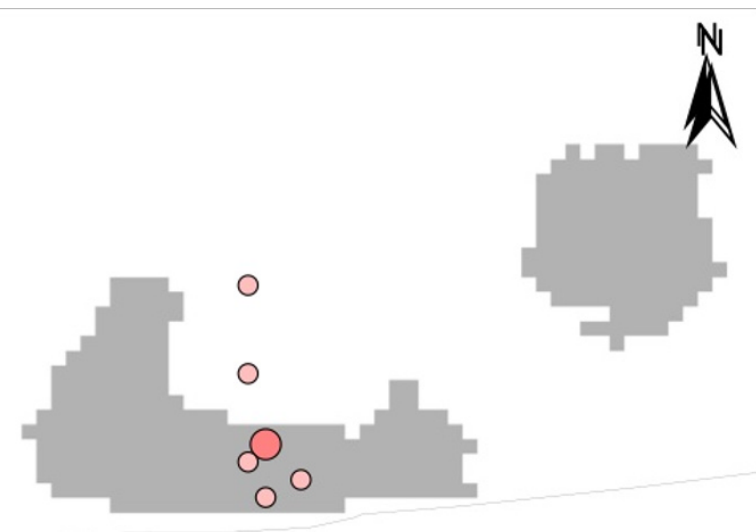

$0 \quad 10$ Kilometers

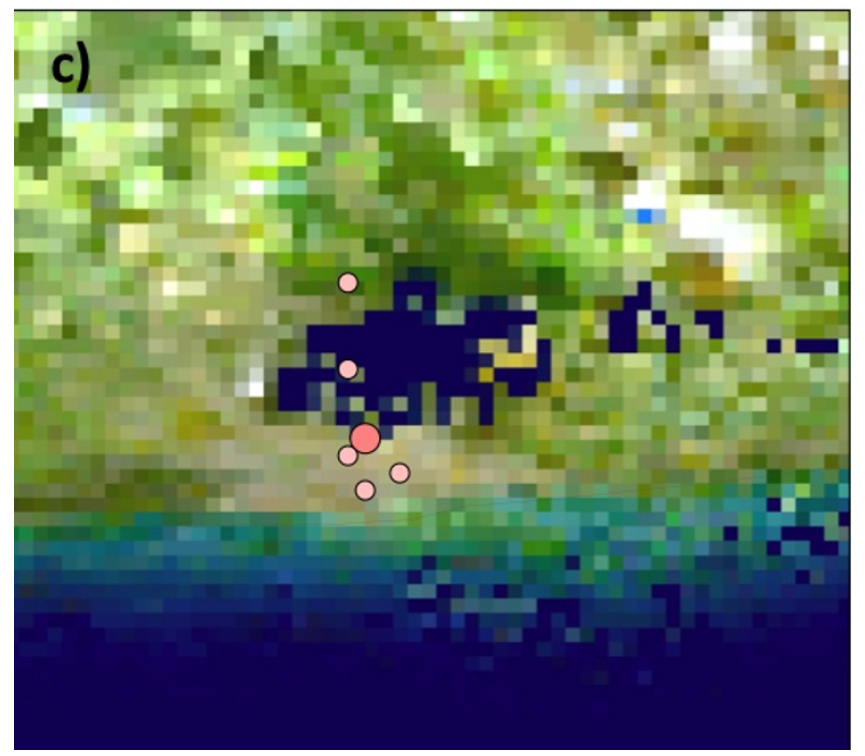

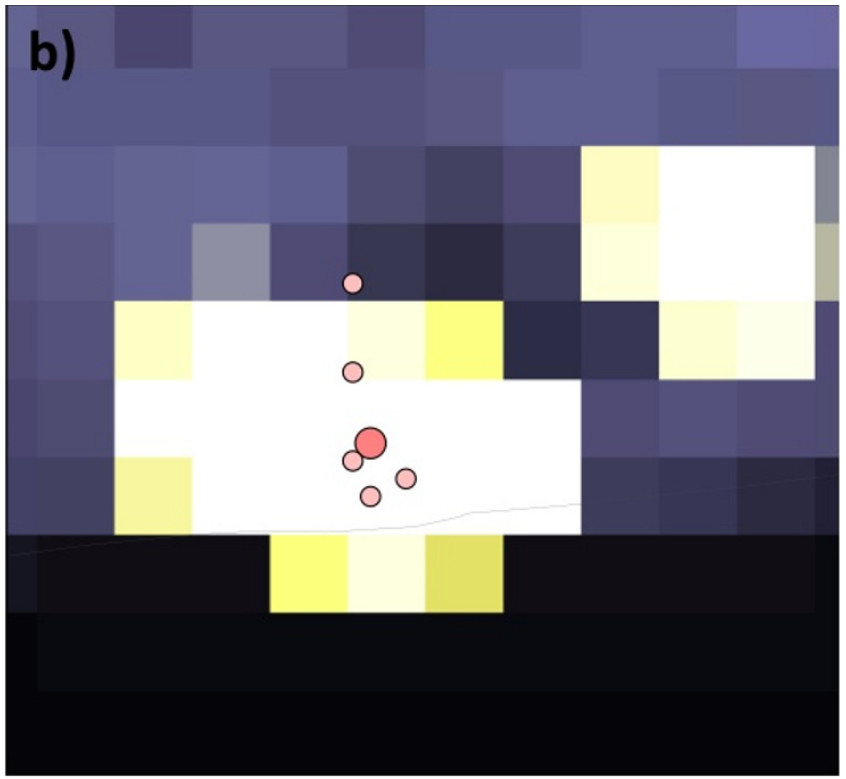

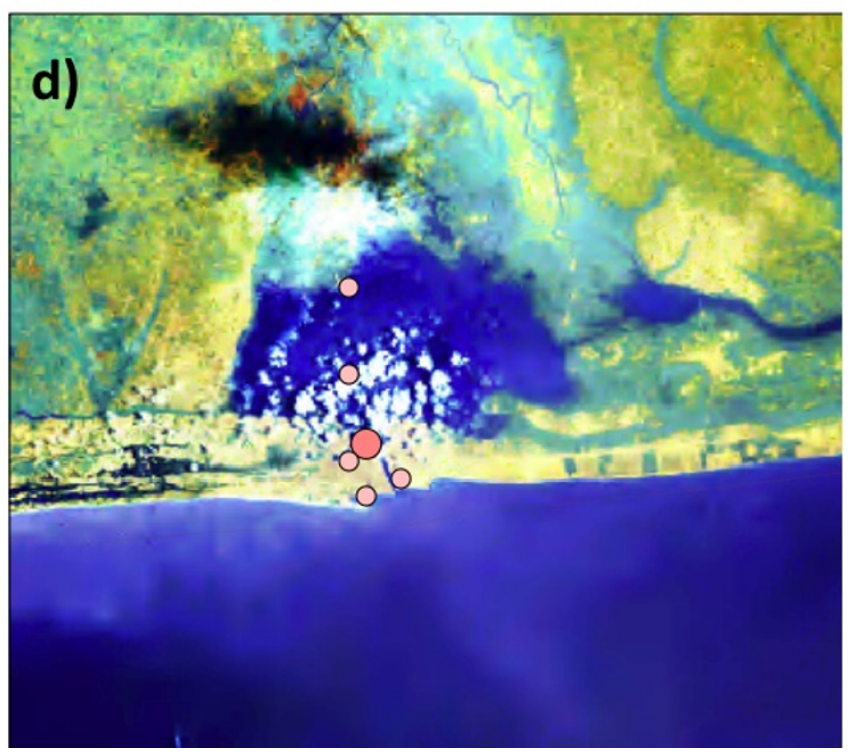

Figure 8

Benin case study. a) Urban-Rural Extent b) Earth at Night (City Lights) 5 km c) Cloud Free Earth I km d) African Land Cover at $150 \mathrm{~m}$.

ally located at lower elevations and have better access to anti-malarial drugs [54]. More importantly, nearly $80 \%$ of APf EIR estimates were taken in areas where climate suitability [26] was six months or less. This results in estimates from short transmission periods being extrapolated to average annual rates, thereby introducing inaccuracies. This points to whether APf EIR estimates would be better presented as monthly measures over a year, highlighting the seasonality, as well as local demographic and ecological factors such as interventions, community wealth and land use e.g. irrigation, which could potentially shorten or prolong the transmission season(s).
Bivariate correlations indicated that population density, elevation and climate were all significantly related to APf EIRs and important factors influencing the risk of transmission. Whilst these data and analyses are crude, in the absence of ground-truth data they provide some useful insights into potentially important associations, which can be followed up in more detail and depth. This work also highlights the advantages of using state of the art GIS tools and remote sensing (RS) technologies [55], especially with changes in population and climate becoming increasingly important to monitor in under-resourced regions of the world such as sub-Saharan Africa [8,9]. 


\section{a)}
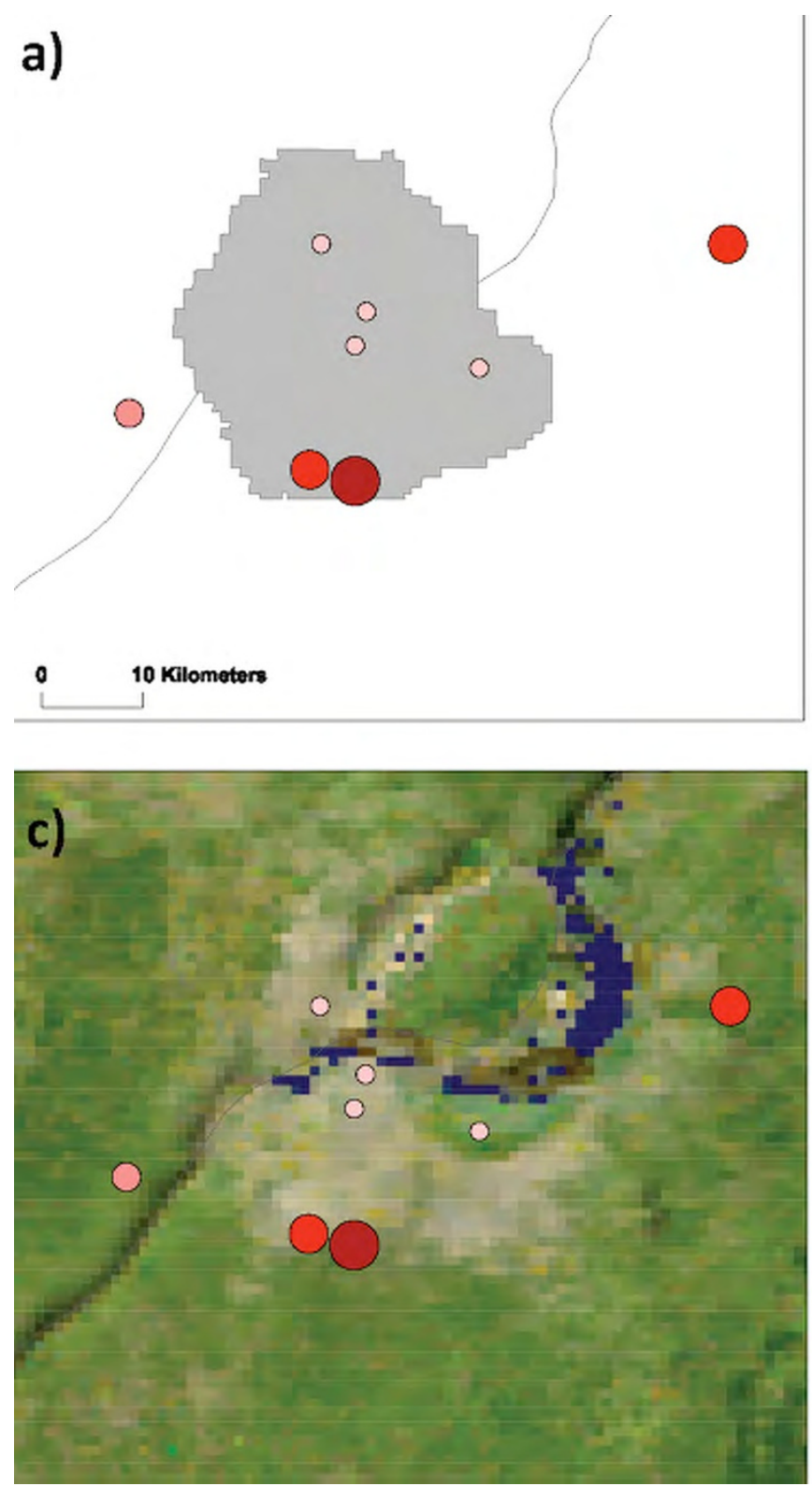
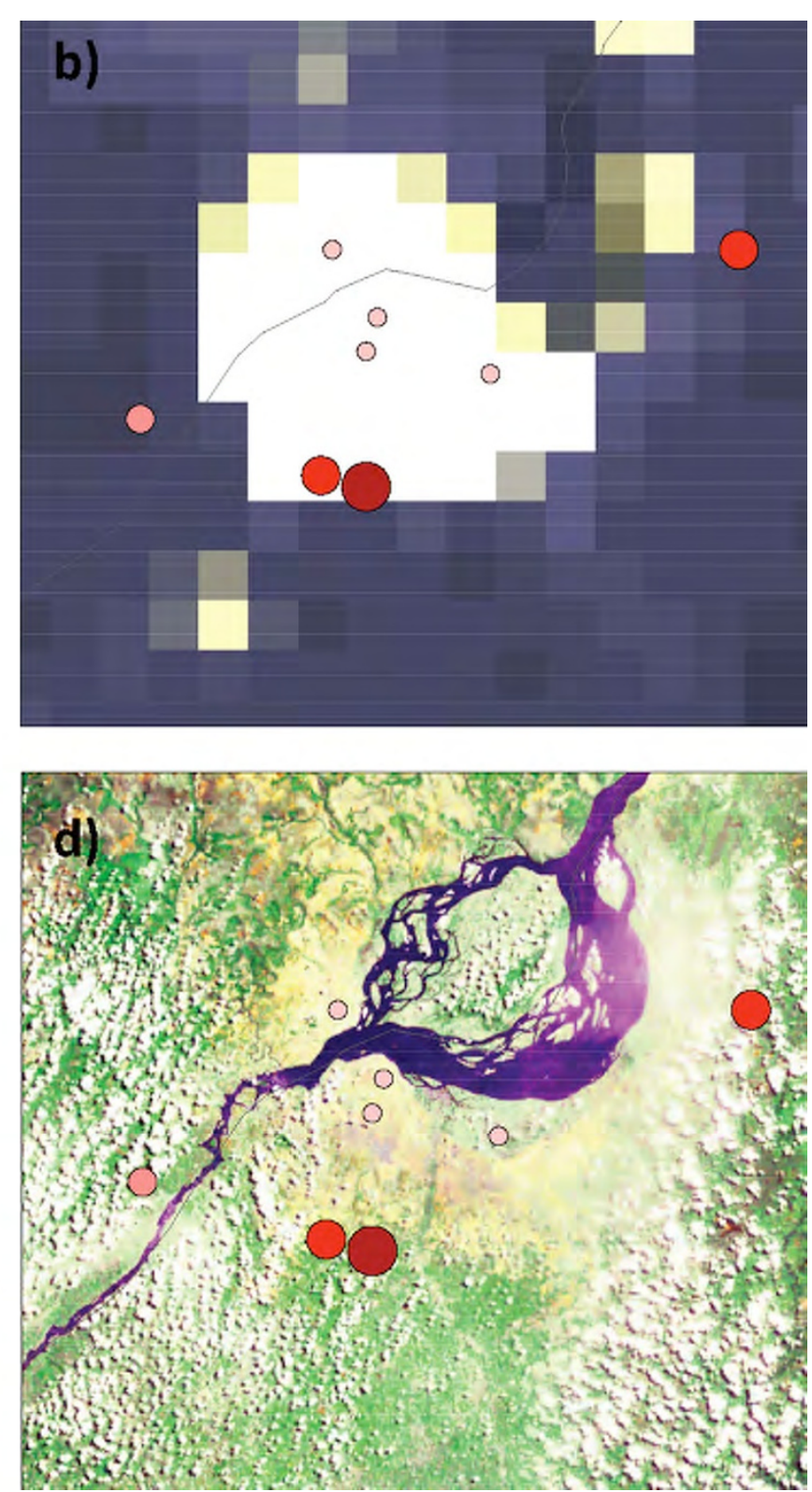

\section{Figure 9}

Republics of Congo case study. a) Urban-Rural Extent b) Earth at Night (City Lights) $5 \mathrm{~km} \mathrm{c)} \mathrm{Cloud} \mathrm{Free} \mathrm{Earth} \mathrm{I} \mathrm{km} \mathrm{d)}$ African Land Cover at $150 \mathrm{~m}$.

The work on the methods used to measure APf EIRs is the most comprehensive review available. It highlights the overall increasing trend over time with a total of 21 measurements recorded in 1980-84, compared with 71 in 1995-99. Of note, however, few transmission studies have been undertaken in recent years. The reason for this lack of work is unclear, but may be related to the limited infrastructure and overall lack of financial resources, trained staff, vector ecologists and medical entomologists on the ground [56]. This may also explain why the methods have varied so much over time, with the more labour intensive and specialized method of HBC to catch bloodfed mosquitoes and the sporozoite dissection technique, being replaced with different combinations of PSC, light traps, ELISA and PCR, which are quicker and simpler. This shift in methodological approaches is probably due to both a lack of human and financial resources, and ethical reasons related to the increasing prevalence of drug resistance across the continent [57].

The use of so many different methods has reduced the ability to compare malaria transmission dynamics within 
and between populations over time. Although there have been attempts to calibrate and understand the relationship between the different HBC [58-64] and sporozoite detection [65-72] methods, the advantages and disadvantages of each method have not been thoroughly examined, and it is still not known how they compare over long periods of time in different settings. This highlights the need for a simpler and more standardized method for measuring APf EIRs, a point previously emphasized by Service [3] and Hay et al [4]. Alternative approaches such as the use of immunological tools (in combination with entomology) also need to be considered, as they have the potential to evaluate the medium- and long-term trends of transmission, and determine the influence of Anopheles vectors species on the regulation of antibody responses to $P$. falciparum [73-75]. This is critical for future studies to better understand the complexities of transmission and the impact of the changes occurring across Africa in terms of urbanization, climate change and large-scale intervention and control programmes involving the mass distribution of ITNs and extensive IRS [43-49].

This current study shows that there are clear and significant differences between urban and rural populations, when APfEIRs are measured using all methods (in accordance with Hay et al [6]), or HBC and dissection. However, these trends were not evident when other method combinations were used, nor when other demographic and ecological factors were stratified by different methods. The reasons may be that there is great variability within each method, and transmission heterogeneity within each location [76-79], both important factors that potentially were not taken into account. Most studies provided little or no explanation regarding mosquito distribution patterns, the rationale behind the choice of locations, houses, or trap placements, nor information on the human collectors, time of day, or frequency of mosquito collections. Further, it was found that PSC-based studies [80-83] did not routinely adjust for the different feeding and resting patterns of the mosquito species, an omission, which may be important in locations where vectors often rest outdoors after feeding e.g. Anopheles arabiensis [84].

Although they are difficult to measure, phenotypic variables like exophily, and genotypic variation in vector competence are also important considerations. Our simple comparisons between An. gambiae s.l and An. funestus presence show how crucial it is to take the Anopheles species characteristics and ecological niches into account. Malaria transmission appears to vary greatly by mosquitoes species, depending upon the land use, population density, elevation and climatic parameters [6]. Overall, APf EIRs were twice as high in locations where both $A n$. gambiae s.l and An. funestus were present, compared with locations which only comprised An. gambiae s.l. The great- est differences and highest APf EIRs occurred in locations of low population densities i.e. rural, those at elevations of 500 to $1,000 \mathrm{~m}$ and where periods of suitable climate exceeded six months.

These preliminary findings indicate that An. funestus is an important, yet potentially underappreciated, vector contributing to high levels of malaria transmission across sub-Saharan Africa. This may help to explain why some populations in close proximity have vastly different APf EIRs, as exemplified in Senegal, in the village of Dielmo where An. funestus was abundant and transmission $10 \times$ higher than the village Ndiope ( $5 \mathrm{~km}$ away), where An. funestus was rare $[17,18]$. Furthermore, An. funestus is seldom found in urban areas, and, where rainfall is confined to a single season each year, is typically most abundant at the end of that season and beginning of the dry season that follows $[17,75,76,85-89]$. Hence, in line with the other factors considered here, one important role of $A n$. funestus is in extending the transmission season in rural areas. More specific research on this vector species is critical - it is a notoriously difficult vector to find in the field, catch and colonise.

The three case studies presented in this paper provide further insight into the ecological factors influencing the diverse mosquito distributions and P. falciparum malaria epidemiology across sub-Saharan Africa. Of note, and perhaps of most concern is the great variation in risk that occurs within relatively small geographical areas, especially in and around urban areas. The implications for a growing urban Africa are unclear. Will urbanization decrease the risk of malaria? Will the mosquito vectors commonly found in peri-urban or adjacent rural areas adapt to urban environments and increase the risk of malaria? How will we measure this? An improved approach to measurement will have numerous ramifications, some perhaps not widely anticipated. For instance differences in transmission intensity, and corresponding immunity, might help to explain circumstances in which frequencies of drug failure differ, far more than frequencies of drug-resistance markers, between urban and surrounding rural areas [90]. This review highlights the complexity and multiplicity of malaria transmission, and serves as a foundation from which to move forward, to develop sensible and realistic methods for measuring malaria transmission in Africa today and for the future.

\section{Competing interests}

The authors declare that they have no competing interests.

\section{Authors' contributions}

LKH designed the study, identified data sources, carried out the data analysis and wrote the first draft of the manuscript. EM conceived the idea for the article and contrib- 
uted significantly to the formatting and writing of the manuscript.

\section{Acknowledgements}

We thank Rousseau Djouaka from the International Institute of Tropical Agriculture (IITA), Cotonou, Bénin for assistance in interpreting in French language papers on malaria transmission in Bénin.

\section{References}

I. World Health Organization (WHO): World Malaria Report 2008. WHO Global Malaria Programme [http://www.who.int/malaria/ wmr2008/].

2. Service MW: Studies on sampling larval populations of the Anopheles gambiae complex. Bull World Health Organ 197I, 45:169-180.

3. Service MW: A critical review of procedures for sampling populations of adult mosquitoes. Bull of Entomol Res 1977, 67:343-382.

4. Hay SI, Rogers DJ, Toomer JF, Snow RW: Annual Plasmodium falciparum entomological inoculation rates (EIR) across Africa: literature survey, Internet access and review. Trans $R$ Soc Trop Med Hyg 2000, 94: I I3-127.

5. Robert V, Macintyre K, Keating J, Trape JF, Duchemin JB, Warren M, Beier JC: Malaria transmission in urban sub-Saharan Africa. Am J Trop Med Hyg 2003, 68:169-176.

6. Hay SI, Guerra CA, Tatem AJ, Atkinson PM, Snow RW: Urbanization, malaria transmission and disease burden in Africa. Nat Rev Microbiol 2005, 3:8I-90.

7. Mboera LEG: Sampling techniques for adult Afrotropical malaria vectors and their reliability in the estimation of entomological inoculation rate. Tanzan Health Res Bull 2005, 7(3): $117-124$

8. World Health Organization (WHO): The World Health Report 2007 - A safer future: global public health security in the 2 I st century. 2007 [http://www.who.int/whr/2007/en/index.html]. WHO, Geneva

9. Campbell-Lendrum DH: Climate change: quantifying the health impact at national and local levels. 2007 [http://whqlib doc.who.int/publications/2007/978924/595674 eng.pdf]. WHO, Geneva

10. MacDonald G: The epidemiology and control of malaria Oxford University Press, London; 1957.

II. Birley MH, Charlewood JD: Sporozoite rate and malaria prevalence. Parasitol Today 1987, 3:231-232.

12. Smith DL, Dushoff J, Snow RW, Hay SI: The entomological inoculation rate and Plasmodium falciparum infection in African children. Nature 2005, 438:492-495.

13. Hay SI, Smith D, Snow R: Measuring malaria endemicity from intense to interrupted transmission. Lancet Infect Dis 2008, 8(Suppl):369-378.

14. Smith T, Killeen GF, Lengeler C, Tanner M: Relationships between the outcome of Plasmodium falciparum infection and the intensity of transmission in Africa. Am J Trop Med Hyg 2004, 7 I(2 Suppl):80-86.

15. Killeen GF, Ross A, Smith T: Infectiousness of malaria-endemic human populations to vectors. Am J Trop Med Hyg 2006, 75(2 Suppl):38-45.

16. Molineaux L, Gramiccia G: The Garki project: research on the epidemiology and control of malaria in the Sudan savanna of West Africa. WHO, Geneva; 1980.

17. Fontenille D, Lochouarn L, Diagne N, Sokhna C, Lemasson JJ, Diatta M, Konate L, Faye F, Rogier C, Trape JF: High annual and seasonal variations in malaria transmission by anophelines and vector species composition in Dielmo, a holoendemic area in Senegal. Am J Trop Med Hyg 1997, 56:247-253.

18. Fontenille D, Lochouarn L, Diatta M, Sokhna C, Dia I, Diagne N, Lemasson J], Ba K, Tall A, Rogier C, Trape JF: Four years' entomological study of the transmission of seasonal malaria in Senegal and the bionomics of Anopheles gambiae and $A$. arabiensis. Trans R Soc Trop Med Hyg 1997, 91 1:647-652.

19. Killeen GF, Tami A, Kihonda J, Okumu FO, Kotas ME, Grundmann H, Kasigudi N, Ngonyani H, Mayagaya V, Nathan R, Abdulla S, Charlwood JD, Smith TA, Lengeler C: Cost-sharing strategies combining targeted public subsidies with private-sector delivery achieve high bednet coverage and reduced malaria transmission in Kilombero Valley, southern Tanzania. BMC Infect Dis 2007, 7:121.

20. Killeen GF, Smith TA, Ferguson HM, Mshinda H, Abdulla S, Lengeler $C$, Kachur SP: Preventing childhood malaria in Africa by protecting adults from mosquitoes with insecticide-treated nets. PLoS Med 2007, 4:e229.

21. Killeen GF, Kihonda J, Lyimo E, Oketch FR, Kotas ME, Mathenge E, Schellenberg JA, Lengeler C, Smith TA, Drakeley CJ: Quantifying behavioural interactions between humans and mosquitoes: evaluating the protective efficacy of insecticidal nets against malaria transmission in rural Tanzania. BMC Infect Dis 2006, 6:161.

22. MARA/ARMA (Mapping Malaria Risk in Africa/Atlas du Risque de la Malaria en Afrique) 2005 [http://www.mara.org.za/].

23. CIESIN/CIAT: Gridded Population of the World (GPW), version 3. Palisades, New York CIESIN, Columbia University, Centre for International Earth Science Information Network (CIESIN), Colombia University; Centro Internacional de Agricultura Tropical (CIAT) 2004 [http:// sedac.ciesin.columbia.edu/gpw/].

24. Balk D, Pozzzi F, Yetman G, Nelson A, Diechmann U: Methodologies to Improve Global Population Estimates in Urban and Rural Areas. CIESIN, Colombia University, NewYork, USA; 2004.

25. National Geophysical Data Center (NGDC): Global Digital Elevation Model (ETOPO2)-gridded ( 2 minute by 2 minute) elevation and bathymetry for the world. ESRI® Data \& Maps, Redlands, California, USA; 2004.

26. International Research Institute for Climate and Society (IRI): Seasonal Climatological Suitability for Malaria Transmission. [http://ingrid.Ideo.columbia.edu/maproom/.Health/.Regional/.Africa/ .CSMT/]. IRI/LDEO Climate Data Library, Columbia University, New York

27. Craig MH, Snow RW, Le Suer D: A climate-based distribution model of malaria transmission in sub-Saharan Africa. Parasitology Today 1999, I5: I05-III.

28. CIESIN/IPFRI/CIAT. Global Rural-Urban Mapping Project (GRUMP): Gridded Population of the World, version 3, with urban reallocation (GPW-UR). Palisades, New York CIESIN, Columbia University, Centre for International Earth Science Information Network (CIESIN), Columbia University; International Food Policy Research Institute (IPFRI), the World Bank; and Centro Internacional de Agricultura Tropical (CIAT) 2004 [http://sedac.ciesin.columbia.edu/gpw/].

29. Sutton P, Roberts D, Elvidge C, Baugh K: Census from Heaven: an estimate of the global human population using nighttime satellite imagery. Int J Remote Sens 200I, 22:306I-3076.

30. NASA: Visible Earth - World at Night produced by mosaicking Defense Meteorological Satellite Program (DMSP) Operational Linescan System (OLS) satellite images. ESRI $\mathbb{R}$ Data \& Maps, Redlands, California, USA; 2004.

31. NASA: Visible Earth - World Cloud Free image data set from Moderate Resolution Imaging Spectroradiometer (MODIS) satellite images. ESRI@ Data \& Maps, Redlands, California, USA;; 2005.

32. NASA: EarthSat NaturalVue Global Landsat Mosaic - Landsat 7-derived, mosaicked image dataset covering the entire land area of Africa at $\mathbf{1 5 0} \mathrm{m}$ resolution (Earth Satellite Corporation). ESRI@ Data \& Maps, Redlands, California, USA; 2005.

33. Burkot TR, Williams JL, Schneider I: Identification of Plasmodium falciparum-infected mosquitoes by a double antibody enzyme-linked immunosorbent assay. Am J Trop Med Hyg 1984, 33:783-788.

34. Scott JA, Brogdon WG, Collins FH: Identification of single specimens of the Anopheles gambiae complex by the polymerase chain reaction. Am J Trop Med Hyg 1993, 49:520-529.

35. Rossi P, Belli A, Mancini L, Sabatinelli G: Enquête entomologique longitudinale sur la transmission du paludisme à Ouagadougou (Burkina Faso). Parassitologia 1986, 28: I-15. [in French]

36. Akogbéto $M$, Chippaux JP, Coluzzi M: Le paludisme urbain côtier à Cotonou (République du Bénin). Étude entomologique. Revue d'Epidémiologie et Santé Publique 1992, 40:233-239. [in French]

37. Akogbeto $M$ : Étude entomologique sur la transmission du paludisme côtièr lagunaire: cas d'un village construit sur un lac d'eau sâumatre. Annales de la Société Belge de Médecine Tropicale 1995, 75:219-227. [in French]

38. Akogbéto M, Nahum A: Impact des moustiquaires impregnees de deltamethrine sur la transmission du paludisme dans un 
milieu cotier lagunaire, Benin. Bulletin de la Société de Pathologie Exotique 1996, 89:291-298. [in French]

39. Karch S, Asidi N, Manzambi ZM, Salaun JJ: La faune anophélienne et la transmission du paludisme humain àKinshasa (Zaïre). Bulletin de la Société de Pathologie Exotique 1992, 85:304-309. [in French]

40. Karch S, Garin B, Asidi N, Manzambi Z, Salaun J], Mouchet J: Moustiquaires imprégnées contre le paludisme au Zaïre. Annales de la Société Belge de Médecine Tropicale 1993, 73:37-53. [in French]

41. Trape JF, Zoulani A: Études sur le paludisme dans une zone de mosaïque forêt-savane d'Afrique centrale, la region de Brazzaville. I. Résultats des enquêtes entomologiques. Bulletin de la Société de Pathologie Exotique 1987, 80:84-99. [in French]

42. Trape JF, Zoulani A: Malaria and urbanization in Central Africa: the example of Brazzaville. Part II: results of entomological surveys and epidemiological analysis. Trans $R$ Soc Trop Med Hyg 1987, $81: 10-18$.

43. The Global Fund to Fight AIDS, Tuberculosis, and Malaria. Fighting malaria [http://www.theglobalfund.org/en/malaria/]

44. The President's Malaria Initiative (PMI) [http://www.fighting malaria.gov/]

45. The World Bank. The World Bank Global Strategy \& Booster Program [http://web.worldbank.org/WBSITE/EXTER NAL/TOPICS/EXTHEALTHNUTRITIONANDPOPULATION/EXT MALARI0,,contentMDK:20461038 pagePK:21 0058 piPK:21 0062 th eS itePK:377598,00.html]

46. The US President's Malaria Initiative. Lancet 2006, 368:I.

47. Loewenberg S: The US President's Malaria Initiative: 2 years on. Lancet 2007, 370:1893-1894.

48. Is malaria eradication possible? Lancet 2007, 370: 1459 .

49. Roberts L, Enserink M: Malaria. Did they really say ... eradication? Science 2007, 3 I8: I544-I545.

50. United Nations (UN): World Urbanization Prospects. The 2007 Revision. UN Population Division ESA/P/WP/205 2008.

5I. Bryan JH: Anopheles gambiae and A. melas at Brefet, The Gambia, and their role in malaria transmission. Ann Trop Med Parasitol 1983, 77:1-12

52. Mbogo CM, Mwangangi JM, Nzovu J, Gu W, Yan G, Gunter JT, Swalm C, Keating J, Regens JL, Shililu JI, Githure JI, Beier JC: Spatial and temporal heterogeneity of Anopheles mosquitoes and Plasmodium falciparum transmission along the Kenyan coast. Am J Trop Med Hyg 2003, 68:734-742.

53. Bigoga JD, Manga L, Titanji VP, Coetzee M, Leke RG: Malaria vectors and transmission dynamics in coastal south-western Cameroon. Malar 」 2007, 6:5

54. Sylla EH, Lell B, Kun JF, Kremsner PG: Plasmodium falciparum transmission intensity and infection rates in children in Gabon. Parasitol Res 200I, 87:530-533.

55. Hay SI, Randolph SE, Rogers DF, Baker JR, Muller R, Rollinson D: Remote Sensing and Geographical Information Systems in Epidemiology (Advances in Parasitology) Academic Press 2000.

56. World Health Organization (WHO): Malaria Vector Surveillance in Africa: building up malaria entomological skills at the level of national malaria control programmes is the way forward. Issue I African Network on Vector Resistance to Insecticides (ANVR) Newsletter; 2006.

57. Sibley CH, Barnes KI, Watkins WM, Plowe CV: A network to monitor antimalarial drug resistance: a plan for moving forward. Trends Parasitol 2008, 24:43-48. Epub 2007 Nov 26. Review

58. Lines JD, Curtis CF, Wilkes TJ, Njunwa KJ: Monitoring human-biting mosquitoes (Diptera:Culicidae) in Tanzania with lighttraps hung beside mosquito nets. Bull Entomol Res |99|, 81:77-84.

59. Mbogo CN, Glass GE, Forster D, Kabiru EW, Githure Il, Ouma JH Beier JC: Evaluation of light traps for sampling anopheline mosquitoes in Kilifi, Kenya. J Am Mosq Control Assoc 1993, 9:260-263.

60. Davis JR, Hall T, Chee EM, Majala A, Minjas J, Shiff CJ: Comparison of sampling anopheline mosquitoes by light-trap and humanbait collections indoors at Bagamoyo, Tanzania. Med Vet Entomol 1995, 9:249-255.

6I. Costantini C, Sagnon NF, Sanogo E, Merzagora L, Coluzzi M: Relationship to human biting collections and influence of light and bednet in CDC light-trap of West African malaria vectors. Bull Entomol Res 1998, 88:503-5।I.
62. Mathenge EM, Omweri GO, Irungu LW, Ndegwa PN, Walczak E, Smith TA, Killeen GF, Knols BGJ: Comparative field evaluation of the Mbita trap, CDC light trap and the human landing catch for sampling of malaria vectors in western Kenya. Am J Trop Med Hyg 2004, 70:33-37.

63. Magbity EB, Lines JD: Spatial and temporal distribution of Anopheles gambiae s.l. (Diptera: Culicidae) in two Tanzanian villages: implications for designing mosquito sampling routines. Bull Entomol Res 2002, 92:483-488.

64. Mathenge EM, Misiani GO, Oulo DO, Irungu LW, Ndegwa PN, Smith TA, Killeen GF, Knols BG: Comparative performance of the Mbita trap, CDC light trap and the human landing catch in the sampling of Anopheles arabiensis, An. funestus and culicine species in a rice irrigation in western Kenya. Malar J 2005, 4:7.

65. Beier JC, Perkins PV, Wirtz RA, Whitmire RE, Mugambi M, Hockmeyer WT: Field evaluation of an enzyme-linked immunosorbent assay (ELISA) for Plasmodium falciparum sporozoite detection in anopheline mosquitoes from Kenya. Am J Trop Med Hyg 1987, 36:459-468.

66. Beier MS, Schwartz IK, Beier JC, Perkins PV, Onyango F, Koros JK, Campbell GH, Andrysiak PM, Brandling-Bennett AD: Identification of malaria species by ELISA in sporozoite and oocyst infected Anopheles from western Kenya. Am J Trop Med Hyg 1988, 39:323-327.

67. Beier JC, Perkins PV, Koros JK, Onyango FK, Gargan TP, Wirtz RA, Koech DK, Roberts CR: Malaria sporozoite detection by dissection and ELISA to assess infectivity of afrotropical Anopheles (Diptera: Culicidae). J Med Entomol 1990, 27:377-384.

68. Boudin C, Robert V, Verhave JP, Carnevale P, Ambroise-Thomas P: Plasmodium falciparum and $P$. malariae epidemiology in a West African village. Bull World Health Organ 1991, 69:199-205.

69. Adungo NI, Mahadevan S, Mulaya NL, Situbi AP, Githure Jl: Comparative determination of Plasmodium falciparum sporozoite rates in Afrotropical Anopheles from Kenya by dissection and ELISA. Ann Trop Med Parasitol I99I, 85:387-394.

70. Sokhna CS, Diagne N, Lochouarn L, Rogier C, Trape JF, Spiegel A, Fontenille $D$ : Comparative evaluation of the plasmodial infection of Anopheles using ELISA and dissection. Consequences for the estimation of the transmission of malaria in 1995 in Ndiop, Senegal. Parasite 1998, 5:273-279. [in French]

7I. Fontenille D, Meunier JY, Nkondjio CA, Tchuinkam T: Use of circumsporozoite protein enzyme-linked immunosorbent assay compared with microscopic examination of salivary glands for calculation of malaria infectivity rates in mosquitoes (Diptera: Culicidae) from Cameroon. J Med Entomol 200 I, 38:45I-454

72. Sylla EH, Kun JF, Kremsner PG: Mosquito distribution and entomological inoculation rates in three malaria-endemic areas in Gabon. Trans $R$ Soc Trop Med Hyg 2000, 94:652-656.

73. Drakeley CJ, Corran PH, Coleman PG, Tongren JE, McDonald SL, Carneiro I, Malima R, Lusingu J, Manjurano A, Nkya WM, Lemnge MM, Cox J, Reyburn H, Riley EM: Estimating medium- and long-term trends in malaria transmission by using serological markers of malaria exposure. Proc Natl Acad Sci USA 2005, 102:5 I08-5 I I 3.

74. Corran P, Coleman P, Riley E, Drakeley C: Serology: a robust indicator of malaria transmission intensity? Trends Parasitol 2007, 23:575-82. Epub 2007 Nov 7. Review

75. Sarr JB, Remoue F, Samb B, Dia I, Guindo S, Sow C, Maiga S, Tine S, Thiam C, Schacht AM, Simondon F, Konate L, Riveau G: Evaluation of antibody response to Plasmodium falciparum in children according to exposure of Anopheles gambiae s.I or Anopheles funestus vectors. Malar J 2007, 6: II7.

76. Smith T, Charlwood JD, Takken W, Tanner M, Spiegelhalter DJ: Mapping the densities of malaria vectors within a single village. Acta Trop 1995, 59: I- 18.

77. Ribeiro JM, Seulu F, Abose T, Kidane G, Teklehaimanot A: Temporal and spatial distribution of anopheline mosquitoes in an Ethiopian village: implications for malaria control strategies. Bull World Health Organ 1996, 74:299-305.

78. Mboera LE, Kihonda J, Braks MA, Knols BG: Influence of centers for disease control light trap position, relative to a humanbaited bed net, on catches of Anopheles gambiae Short report: and Culex quinquefasciatus in Tanzania. Am J Trop Med Hyg 1998, 59:595-596. 
79. Oyewole IO, Awolola TS: Impact of urbanisation on bionomics and distribution of malaria vectors in Lagos, southwestern Nigeria. J Vector Borne Dis 2006, 43:173-178.

80. Rossi P, Belli A, Mancini L, Sabatinelli G: Enquête entomologique longitudinale sur la transmission du paludisme à Ouagadougou (Burkina Faso). Parassitologia 1986, 28: I-I5. [in French]

8I. Thomson MC, D'Alessandro U, Bennett S, Connor SJ, Langerock $P$, Jawara M, Todd J, Greenwood BM: Malaria prevalence is inversely related to vector density in The Gambia, West Africa. Trans R Soc Trop Med Hyg 1994, 88:638-643.

82. Modiano D, Petrarca V, Sirima BS, Nebié I, Diallo D, Esposito F, Coluzzi M: Different response to Plasmodium falciparum malaria in West African sympatric ethnic groups. Proc Natl Acad Sci USA 1996, 93:13206-13211.

83. Aniedu I: Dynamics of malaria transmission near two permanent breeding sites in Baringo district, Kenya. Indian J Med Res 1995, 105:206-2।I.

84. Tirados I, Costantini C, Gibson G, Torr SJ: Blood-feeding behaviour of the malarial mosquito Anopheles arabiensis : implications for vector control. Med Vet Entomol 2006, 20:425-437.

85. Björkman A, Hedman P, Brohult J, Willcox M, Diamant I, Pehrsson $\mathrm{PO}$, Rombo L, Bengtsson E: Different malaria control activities in an area of Liberia- effects on malariometric parameters. Ann Trop Med Parasitol 1985, 79:239-246.

86. Trape JF, Rogier C, Konate L, Diagne N, Bouganali H, Canque B, Legros F, Badji A, Ndiaye G, Ndiaye P, Brahimi K, Faye O, Druilhe P, Pereira Da Silva L: The Dielmo Project: a longitudinal study of natural malaria infection and the mechanisms of protective immunity in a community living in a holoendemic area of Senegal. Am J Trop Med Hyg 1994, 5 I: I23-137.

87. Elissa N, Karch S, Bureau P, Ollomo B, Lawoko M, Yangari P, Ebang $B$, Georges AJ: Malaria transmission in a region of savanna forest mosaic, Haut-Ogooue, Gabon. J Am Mosquito Control Assoc 1999, 15:15-23.

88. Elissa N, Migot-Nabias F, Luty A, Renaut A, Touré F, Vaillant M, Lawoko M, Yangari P, Mayombo J, Lekoulou F, Tshipamba P, Moukagni R, Millet P, Deloron P: Relationship between entomological inoculation rate, Plasmodium falciparum prevalence rate, and incidence of malaria attack in rural Gabon. Acta Tropica 2003, 85:355-36I.

89. Okello PE, Van Bortel W, Byaruhanga AM, Correwyn A, Roelants P, Talisuna A, D'Alessandro U, Coosemans M: Variation in malaria transmission intensity in seven sites throughout Uganda. Am J Trop Med Hyg 2006, 75:219-225.

90. Meissner PE, Mandi G, Mockenhaupt FP, Witte S, Coulibaly B, Mansmann U, Frey C, Merkle H, Burhenne J, Walter-Sack I, Müller O: Marked differences in the prevalence of chloroquine resistance between urban and rural communities in Burkina Faso. Acta Trop 2008, 105:8I-86. Epub 2007 Aug 15

Publish with Bio Med Central and every scientist can read your work free of charge

"BioMed Central will be the most significant development for disseminating the results of biomedical research in our lifetime. "

Sir Paul Nurse, Cancer Research UK

Your research papers will be:

- available free of charge to the entire biomedical community

- peer reviewed and published immediately upon acceptance

- cited in PubMed and archived on PubMed Central

- yours - you keep the copyright

Submit your manuscript here:

http://www.biomedcentral.com/info/publishing_adv.asp
BioMedcentral 